\title{
ASUPAN SERAT, BEBAN GLIKEMIK DAN KADAR GLUKOSA DARAH PADA PASIEN DIABETES MELITUS TIPE 2
}

\author{
Elida Soviana $^{1}$, Dia Maenasari \\ ${ }^{1,2}$ Program Studi Ilmu Gizi, Fakultas Ilmu Kesehatan, Universitas \\ Muhammadiyah Surakarta \\ Email : 12elida.soviana@ums.ac.id,2diamaenasari@gmail.com
}

\begin{abstract}
ABSTRAK
Penatalaksanaan terapi pada diabetes melitus ditujukan untuk mengontrol kadar glukosa darah yang dapat dilakukan dengan cara mengonsumsi makanan tinggi serat dan beban glikemik rendah. Tujuan penelitian yaitu untuk mengetahui hubungan antara serat dan beban glikemik terhadap kadar glukosa darah pada pasien diabetes melitus tipe 2 di Klinik Jasmine 2 Surakarta. Penelitian observasional dengan pendekatan cross-sectional dan teknik pengambilan subjek secara consecutive sampling sebanyak 40 orang sesuai kriteria inklusi dan eksklusi. Pengumpulan data asupan serat dan karbohidrat diperoleh melalui wawancara langsung menggunakan metode Semi Quantitative Food Frequency Questionnaire (SQ-FFQ) satu bulan terakhir dan pengumpulan data kadar glukosa darah puasa menggunakan metode spektrofotometri. Beban glikemik makanan didapatkan dari hasil analisis jumlah gram karbohidrat pada setiap makanan dikalikan dengan indeks glikemik makanan tersebut kemudian dibagi 100 . Analisis data menggunakan software SPSS for windows versi 20 dan analisis data dengan uji Pearson Product Moment. Hasil penelitian menunjukkan sebanyak $100 \%$ subjek penelitian memiliki asupan serat yang rendah dengan rata-rata asupan serat sebesar 14,33 $\pm 2,72$ gram. Sebanyak 55\% subjek penelitian memiliki beban glikemik yang tinggi dengan rata-rata sebesar 121,19 $\pm 24,29$ gram. Persentase subjek penelitian yang memiliki kadar glukosa darah puasa normal dan tinggi masing-masing sebanyak 50\% dengan rata-rata kadar glukosa darah puasa sebesar $149,25 \pm 25 \mathrm{mg} / \mathrm{dL}$. Hasil uji hubungan antara asupan serat dengan kadar glukosa darah puasa menunjukkan nilai $\mathrm{p}=0,042$, sedangkan beban glikemik dengan kadar glukosa darah puasa menunjukkan nilai $p=0,001$. Terdapat hubungan antara asupan serat dan beban glikemik terhadap kadar glukosa darah pada pasien diabetes melitus tipe 2 di Klinik Jasmine 2 Surakarta.
\end{abstract}

\section{Kata Kunci: Asupan serat, beban glikemik, kadar glukosa darah puasa}

\begin{abstract}
Management of therapy in diabetes mellitus is intended to control blood glucose levels which can be done by consuming foods high in fiber and low glycemic load. The purpose of this research is to determine the relationship between fiber and glycemic load on blood glucose levels in patients with type 2 diabetes mellitus at Klinik Jasmine 2 Surakarta. Observational research with a crosssectional approach and using consecutive sampling with total sample of 40 people
\end{abstract}


according to the inclusion and exclusion criteria. Data collection on fiber and carbohydrate intake was obtained through direct interviews using the Semi Quantitative Food Frequency Questionnaire (SQ-FFQ) method in the past month and data collection on fasting blood glucose levels using spectrophotometric methods. The glycemic load of food was obtained from the analysis of the number of grams of carbohydrates in each food multiplied by the glycemic index of the food then divided by 100. Data analysis using SPSS software for windows version 20 and data analysis using the Pearson Product Moment test. The results showed that $100 \%$ of subjects had low fiber intake with an average fiber intake of $14.33 \pm$ 2.72 grams. As many as $55 \%$ of subjects had a high glycemic load with an average of $121.19 \pm 24.29$ grams. The percentage of subjects who had normal and high fasting blood glucose levels was $50 \%$ each with an average fasting blood glucose level of $149.25 \pm 25 \mathrm{mg} / \mathrm{dL}$. The test results of the relationship between fiber intake with fasting blood glucose levels showed a $\mathrm{p}$ value $=0.042$, while glycemic load with fasting blood glucose levels showed a $\mathrm{p}$ value $=0.001$. There is a relationship between fiber intake and glycemic load on blood glucose levels in patients with type 2 diabetes mellitus at Klinik Jasmine 2 Surakarta.

\section{Keywords: Fiber intake, glycemic load, fasting blood glucose levels}

\section{PENDAHULUAN}

Diabetes melitus merupakan salah satu penyakit metabolik kronis yang disebabkan oleh kelainan sekresi insulin, kerja insulin atau keduanya dan ditandai dengan terjadinya kadar glukosa dalam darah melebihi normal (Perkeni, 2015). Hiperglikemia yang terjadi berulang-ulang pada penderita diabetes berhubungan dengan kerusakan jangka panjang, disfungsi dan/atau kegagalan beberapa organ tubuh terutama pada mata, ginjal, saraf dan dapat meningkatkan resiko terjadinya penyakit kardiovaskuler (Goldenberg dan Punthakee, 2013)

Di Indonesia, sebanyak 90\% dari total penderita diabetes melitus merupakan penderita diabetes melitus tipe 2 (Kemenkes, 2014). Prevalensi penderita diabetes melitus usia $\geq 15$ tahun di Indonesia pada tahun 2018 diperkirakan sebesar 2\%. Jika dibandingkan dari prevalensi tahun 2015 yaitu sebesar 2,1\%, prevalensi penderita diabetes melitus pada tahun 2018 mengalami penurunan namun masih tergolong tinggi (Riskesdas, 2018). Tingginya prevalensi jumlah penderita diabetes dikarenakan belum semua penderita diabetes mengetahui bahwa dirinya menderita diabetes dan kurang mendapatkan akses pelayanan kesehatan yang memadai (Perkeni, 2015). Salah satu provinsi di Indonesia yang memiliki prevalensi penderita diabetes melitus usia $>15$ tahun lebih tinggi daripada prevalensi di Indonesia pada tahun 2018 yaitu Provinsi Jawa Tengah (2,1\%) (Riskesdas, 2018).

Penatalaksanaan diabetes melitus ditujukan untuk mengontrol kadar glukosa darah dan mencegah terjadinya penyakit komplikasi pada penderita dengan menerapkan empat pilar yaitu memberikan edukasi, terapi nutrisi medis, melakukan aktivitas fisik dan terapi farmakologi. Terapi nutrisi medis merupakan bagian penting dari penatalaksanaan diabetes melitus yang salah satunya dilakukan dengan 
pengaturan diet, seperti mengonsumsi sumber karbohidrat kompleks dengan indeks glikemik rendah atau beban glikemik makanan rendah dan mengonsumsi makanan tinggi serat (Perkeni, 2018).

Penderita diabetes mellitus yang mengkonsumsi serat dalam jumlah yang cukup dapat membantu mengontrol kadar glukosa darah penderita. Serat terutama serat larut air yang masuk bersama makanan akan menyerap banyak cairan di dalam lambung dan membentuk makanan menjadi lebih viskos. Makanan yang lebih viskos akan memperlambat proses pencernaan sehingga proses penyerapan nutrisi seperti glukosa akan terjadi secara lambat (Mahan dan Escot, 2008). Penyerapan glukosa yang lambat akan menyebabkan kadar glukosa darah menurun (Chandalia dkk, 2000). Konsumsi serat yang baik bagi penderita diabetes melitus adalah 20-35 gram/hari dengan anjuran konsumsi serat sebanyak 25 gram/hari (Perkeni, 2018). Hasil penelitian yang dilakukan oleh Immawati dan Wirawanni (2014), menunjukkan bahwa konsumsi tinggi serat berhubungan dengan menurunnya kadar glukosa darah puasa dan kadar glukosa 2 jam postprandial pada penderita diabetes melitus tipe 2 .

$$
\text { Beban glikemik }
$$

menggambarkan tentang respon kadar glukosa darah terhadap jumlah dan jenis karbohidrat tertentu dalam makanan yang dikonsumsi dan indeks glikemik makanan (Burani danLongo, 2006). Konsumsi BG tinggi ketika tubuh mengalami resistensi insulin menyebabkan tubuh akan merespon dengan meningkatkan sekresi insulin. Sekresi insulin yang terus meningkat akan menyebabkan sel- $\beta$ pankreas kelelahan dan pada akhirnya sel- $\beta$ pankreas tidak dapat memenuhi kebutuhan insulin, sehingga glukosa darah tetap tinggi. Sedangkan konsumsi makanan dengan BG rendah akan menurunkan laju penyerapan glukosa dan menekan sekresi insulin oleh sel- $\beta$ pankreas, sehingga kadar glukosa darah tidak meningkat secara signifikan (Willet dkk, 2002). Hasil penelitian oleh Idris dkk (2014), menyatakan bahwa $95 \%$ responden dengan konsumsi beban glikemik yang tinggi memiliki kadar glukosa darah yang tidak terkontrol.

Penelitian ini dilakukan untuk mengetahui hubungan antara asupan serat dan beban glikemik pada penderita diabetes mellitus tipe 2 di Klinik Jasmine 2 Surakarta.

\section{METODE PENELITIAN}

Jenis penelitian adalah observasinal, yaitu peneliti melakukan pengamatan pada subjek penelitian dalam kurun waktu tertentu dengan pendekatan cross-sectional. Penelitian ini telah lolos kelaiakan etik oleh Komisi Etik Penelitian Kesehatan Fakultas Kedokteran UMS dengan No. 2230/B.1/KEPK-FKUMS/VIII/2019.

Penelitian dilakukan di Klinik Jasmine 2 Surakarta dengan waktu pengambilan data pada bulan Juli hingga Agustus 2019. Populasi penelitian adalah semua pasien diabetes melitus tipe 2 yang masuk kriteria inklusi dan eksklusi di Klinik Jasmine 2 Surakarta. Kriteria inklusi populasi dan subjek penelitian, antara lain:

a. Subjek tidak memiliki komplikasi penyakit ginjal.

b. Subjek bersedia menjadi responden. 
c. Subjek mampu berkomunikasi dengan baik.

d. Subjek berusia 45-65 tahun.

e. Subjek tidak menjalani diet vegetarian.

f. Subjek rutin dan patuh mengonsumsi obat bagi penderita diabetes melitus tipe 2 seperti metformin dan glimepiride.

Kriteria eksklusi dari populasi dan subjek penelitian yaitu:

a. Subjek meninggal dunia selama penelitian berlangsung.

b. Mengundurkan diri menjadi subjek penelitian.

Jumlah subjek penelitian dihitung menggunakan Rumus Slovin dan diapatkan jumlah subjek penelitian sebanyak 37 orang termasuk lost of follow up nya. Pada penelitian ini jumlah pasien diabetes melitus tipe 2 yang dijadikan subjek penelitian sebanyak 40 orang.

Data asupan serat dan karbohidrat diperoleh dengan menggunakan form Semi Quantitative Food Frequency Questionnaire (SQFFQ) selama satu bulan terakhir, sedangkan data kadar glukosa darah puasa didapatkan dari hasil pemeriksaan darah menggunakan metode spektrofotometri. Asupan serat dihitung dari rata-rata asupan makanan yang mengandung serat selama satu bulan terakhir yang diukur menggunakan metode semi quantitative food frequency questionnaire (SQFFQ) dengan satuan gram. Beban glikemik menggambarkan tentang respon kadar glukosa darah terhadap jumlah dan jenis karbohidrat tertentu dalam makanan yang dikonsumsi dan indeks glikemik makanan. Beban glikemik makanan diperoleh dari penjumlahan beban glikemik per asupan karbohidrat dalam satu hari, dihitung dengan mengalikan indeks glikemik, jumlah gram karbohidrat di dalam makanan dan frekuensi makan dalam satu hari, kemudian dibagi 100 . Kadar glukosa darah yang digunakan adalah kadar glukosa darah puasa (GDP). Pemeriksaan kadar glukosa darah puasa dilakukan setelah responden puasa selama 8 jam dan diukur menggunakan alat spektrofotometer dengan satuan mg/dL. Analisis data menggunakan software SPSS for windows versi 20 menggunakan uji Pearson Product Moment.

\section{HASIL DAN PEMBAHASAN}

\section{Karakteristik Responden}

Berdasarkan hasil penelitian, diketahui karakteriktik responden sebagai berikut:

Tabel 1. Distribusi Responden Menurut Jenis Kelamin dan Usia

\begin{tabular}{llc}
\hline \multicolumn{1}{c}{$\begin{array}{c}\text { Subjek } \\
\text { Penelitian }\end{array}$} & $\begin{array}{c}\text { Jumlah } \\
(\mathrm{n})\end{array}$ & $\begin{array}{c}\text { Persentase } \\
(\%)\end{array}$ \\
\hline Jenis Kelamin & & \\
Laki-laki & 20 & 50 \\
Perempuan & 20 & 50 \\
Usia & & \\
$45-49$ & 2 & 5 \\
$50-64$ & 28 & 70 \\
65 & 10 & 25 \\
\hline
\end{tabular}

Tabel 1 menunjukkan bahwa responden yang mengalami diabetes mellitus tipe 2 untuk responden yang berjenis kelamin laki-laki sama dengan yang perempuan yaitu sebanyak 20 orang $(50 \%)$. Subjek penelitian yang digunakan yaitu berusia antara 45-65 tahun. Berdasarkan Tabel 1, subjek penelitian/responden paling banyak mengalami diabetes melitus tipe 2 adalah kelompok responden dengan usia 50-64 tahun yaitu sebesar 70\% 
dari total responden atau sebanyak 28 orang.

Data usia dan jenis kelamin diperoleh dari form kuesioner identitas subjek penelitian. Pengambilan data dilakukan pada pasien usia 45-65 tahun dikarenakan pada usia diatas 40 tahun, terjadi proses penuaan dan fungsi fisiologis tubuh akan mengalami penurunan yang mengakibatkan kemampuan sel- $\beta$ pankreas juga mengalami penurunan dalam menghasilkan insulin, sehingga meningkatkan risiko kejadian intoleransi glukosa dalam tubuh dan menderita diabetes mellitus (Alwi dkk, 2007).

Data Riskesdas 2018 menunjukkan bahwa prevalensi penderita diabetes melitus berdasarkan diagnosis dokter mengalami peningkatan seiring bertambahnya usia. Peningkatan prevalensi penderita diabetes melitus paling signifikan dimulai dari usia dewasa akhir hingga lansia awal dan berlanjut hingga usia $\leq 65$ tahun serta mengalami penurunan yang signifikan pada usia $>75$ tahun.

\section{Asupan Serat}

Asupan serat diperoleh dari hasil wawancara langsung menggunakan SQ-FFQ selama satu bulan terakhir. Bahan makanan pada form tersebut dianalisis kandungan seratnya menggunakan Nutrisurvey2008 yang telah ditambahkan bahan makanan dalam Tabel Komposisi Pangan Indonesia (TKPI) Tahun 2017. Konsumsi serat yang baik bagi penderita diabetes melitus berkisar antara 20-35 gram/hari dengan anjuran konsumsi serat sebanyak $\geq 25$ gram/hari. Konsumsi serat sebanyak $<25$ gram/hari dikategorikan dalam asupan serat rendah dan konsumsi serat sebanyak $\geq 25$ gram/hari dikategorikan dalam asupan serat cukup. Distribusi responden menurut asupan serat dapat dilihat pada Tabel 2.

Tabel 2. Distribusi Asupan Serat

\begin{tabular}{lc}
\hline Statistik Deskriptif & $\begin{array}{c}\text { Asupan Serat } \\
\text { (g/hari) }\end{array}$ \\
\hline Mean & 14,33 \\
Std. Deviation & 2,72 \\
Minimum & 9,40 \\
Maximun & 22,10 \\
\hline
\end{tabular}

Tabel 2 menunjukkan bahwa nilai rata-rata (mean) asupan serat perhari pada responden sebesar 14,33 gram/hari. Nilai rata-rata tersebut termasuk dalam kategori asupan serat rendah. Data distribusi responden menurut kategori asupan serat per hari menunjukkan bahwa sebanyak 100\% responden memiliki asupan serat yang rendah. Asupan serat didapatkan dari bahan makanan yang memilki kandungan serat. Bahan makanan yang banyak mengandung serat yaitu sayuran, buah-buahan, kacangkacangan, dan beberapa serealia.

Hasil penelitian yang dilakukan menunjukkan bahwa asupan serat oleh semua responden termasuk dalam kategori rendah. Hal ini terbukti dari jumlah bahan makanan yang dikonsumsi hanya sedikit, kurang bervariasi dan frekuensi konsumsinya jarang. Semua responden menyatakan tidak melakukan diet apapun, hanya tidak sering mengonsumsi bahan makanan sumber serat seperti sayur dan buah. Berikut ini merupakan daftar bahan makanan sumber serat yang sering dikonsumsi oleh responden dapat dilihat pada Tabel 3. 
Tabel 3. Daftar BM Sumber Serat yang Sering Dikonsumsi oleh Responden

\begin{tabular}{lccccc}
\hline Bahan Makanan & $\begin{array}{c}\text { Jumlah } \\
\text { Responden } \\
(\mathrm{n})\end{array}$ & $\begin{array}{c}\text { Persentase } \\
(\%)\end{array}$ & $\begin{array}{c}\text { Rata-rata } \\
\text { Konsumsi } \\
(\mathrm{g} / \mathrm{hari})^{*}\end{array}$ & $\begin{array}{c}\text { Kandungan } \\
\text { Serat }(\mathrm{g}) * *\end{array}$ & Frekuensi \\
\hline Tempe & 40 & 100 & 64,32 & 0,9 & $1 \mathrm{x} / \mathrm{hari}$ \\
Wortel & 34 & 85 & 16,03 & 0,2 & $2-4 \mathrm{x} / \mathrm{minggu}$ \\
Bayam & 32 & 80 & 10,72 & 0,1 & $2-4 \mathrm{x} / \mathrm{minggu}$ \\
Pepaya & 32 & 80 & 56,58 & 0,9 & $1 \mathrm{x} / \mathrm{hari}$ \\
Labu siam & 32 & 80 & 6,33 & 0,4 & $2-4 \mathrm{x} / \mathrm{minggu}$ \\
Kacang panjang & 30 & 75 & 6,26 & 0,2 & $2-4 \mathrm{x} / \mathrm{minggu}$ \\
Pisang mas & 30 & 75 & 14,62 & 0,2 & $1 \mathrm{x} / \mathrm{minggu}$ \\
Jeruk manis & 28 & 70 & 14,93 & 0,2 & $1 \mathrm{x} / \mathrm{minggu}$ \\
Biskuit & 28 & 70 & 2,65 & 0,1 & $1-3 \mathrm{x} / \mathrm{bulan}$ \\
Jambu biji & 26 & 65 & 6,83 & 0,2 & $1-3 \mathrm{x} / \mathrm{bulan}$ \\
Brokoli & 24 & 60 & 8,6 & 0,2 & $2-4 \mathrm{x} / \mathrm{minggu}$ \\
Roti putih & 24 & 60 & 0,74 & 0,1 & $1-3 \mathrm{x} / \mathrm{bulan}$ \\
Pisang ambon & 18 & 45 & 27,97 & 0,5 & $1-3 \mathrm{x} / \mathrm{bulan}$ \\
Apel & 12 & 30 & 6,41 & 0,2 & $1-3 \mathrm{x} / \mathrm{bulan}$ \\
Pisang kapok & 12 & 30 & 10,26 & 0,6 & $1 \mathrm{x} / \mathrm{hari}$ \\
Pisang raja & 6 & 15 & 5,71 & 0,3 & $1 \mathrm{x} / \mathrm{hari}$ \\
\hline
\end{tabular}

* Rata-rata konsumsi berdasarkan jumlah responden yang mengonsumsinya

** Kandungan serat didapatkan dari hasil analisis rata-rata konsumsi berdasarkan jumlah responden yang mengonsumsinya

\section{Beban Glikemik}

Beban glikemik diperoleh dengan mengalikan jumlah gram karbohidrat dalam bahan makanan/makanan yang dikonsumsi dengan indeks glikemiknya kemudian dibagi 100. Jumlah gram karbohidrat dalam bahan makanan didapatkan dari hasil analisis kandungan karbohidrat per bahan makanan menggunakan software Nutrisurvey2008. Berat gram bahan makanan yang dianalisis merupakan berat gram bahan makanan yang dikonsumsi dalam sehari. Perhitungan beban glikemik dilakukan pada setiap bahan makanan sumber karbohidrat yang mengandung indeks glikemik, kemudian menjumlahkan hasil perhitungan beban glikemik setiap bahan makanan yang dikonsumsi dalam sehari dengan satuan gram. Hasil penjumlahan beban glikemik dalam sehari kemudian dikategorikan menjadi tiga kategori yaitu beban glikemik rendah $<80$ gram, beban glikemik sedang 80-120 gram dan beban glikemik tinggi >120 gram (Burani, 2006). Distribusi responden menurut beban glikemik dapat dilihat pada Tabel 4 .

Tabel 4. Distribusi Responden Menurut Beban Glikemik

Statistik Deskriptif Beban Glikemik (g)

\begin{tabular}{lc}
\hline Mean & 121,19 \\
Std. Deviation & 24,29 \\
Minimum & 80,10 \\
Maximun & 171,80 \\
\hline
\end{tabular}

Tabel 4 menunjukkan bahwa nilai rata-rata asupan beban glikemik pada responden sebesar 121,19 gram, menunjukkan bahwa asupan beban glikemik yang dikonsumsi per hari termasuk dalam kategori tinggi. Data distribusi responden menurut kategori beban glikemik menunjukkan bahwa sebanyak $45 \%$ responden memiliki kategori asupan beban glikemik yang sedang dan sebanyak 55\% responden memiliki asupan beban glikemik yang 
tinggi. Hal ini berarti sebagian besar subjek penelitian memiliki konsumsi beban glikemik yang berlebih. Berdasarkan hasil penelitian, berikut ini merupakan daftar bahan dengan beban glikemik yang sering dikonsumsi oleh responden:

Tabel 5. Daftar BM dengan Beban Glikemik yang Sering Dikonsumsi oleh Responden

\begin{tabular}{|c|c|c|c|c|c|}
\hline Bahan Makanan & $\begin{array}{c}\text { Jumlah } \\
\text { Responden } \\
\text { (n) }\end{array}$ & $\begin{array}{c}\text { Persentase } \\
(\%)\end{array}$ & $\begin{array}{l}\text { Rata-rata } \\
\text { Konsumsi } \\
\text { (g/hari)* }\end{array}$ & $\begin{array}{c}\text { Beban } \\
\text { Glikemik } \\
\text { (g/hari)** }\end{array}$ & Frekuensi \\
\hline Nasi putih & 40 & 100 & 248,75 & 63,36 & $2-3 x /$ hari \\
\hline Gula pasir & 40 & 100 & 16,76 & 11,06 & $2-3 x /$ hari \\
\hline Singkong & 32 & 80 & 16,64 & 3,66 & 1-3x/bulan \\
\hline Ketan putih & 32 & 80 & 5,12 & 1,18 & 1-3x/bulan \\
\hline Pepaya & 32 & 80 & 56,58 & 3,79 & 1x/hari \\
\hline Pisang mas & 30 & 75 & 14,62 & 2,89 & 1x/minggu \\
\hline Gula aren & 30 & 75 & 2,07 & 1,33 & $1 \mathrm{x} / \mathrm{ming} \mathrm{u}$ \\
\hline Biskuit & 28 & 70 & 2,65 & 1,18 & 1-3x/bulan \\
\hline Tepung terigu & 28 & 70 & 8,64 & 2,81 & 1x/hari \\
\hline Jeruk manis & 28 & 70 & 14,93 & 0,75 & 1x/minggu \\
\hline Kentang & 26 & 65 & 2,69 & 0,2 & 1-3x/bulan \\
\hline Makaroni & 26 & 65 & 2,43 & 0,85 & 1-3x/bulan \\
\hline Jagung & 22 & 55 & 16,9 & 2,88 & $2-4 \mathrm{x} / \mathrm{minggu}$ \\
\hline Mie kering & 20 & 50 & 4,55 & 1,61 & 1-3x/bulan \\
\hline Semangka & 20 & 50 & 8,8 & 0,4 & 1-3x/bulan \\
\hline Pisang ambon & 18 & 45 & 27,97 & 4 & 1-3x/bulan \\
\hline Nasi merah & 16 & 40 & 16,03 & 2,86 & 1-3x/bulan \\
\hline Ubi jalar & 16 & 40 & 6,64 & 0,75 & 1-3x/bulan \\
\hline Nanas & 14 & 34 & 6,86 & 0,36 & 1-3x/bulan \\
\hline Pisang kepok & 12 & 30 & 10,26 & 1,6 & 1x/hari \\
\hline Kurma & 10 & 25 & 1,87 & 0,58 & 1x/hari \\
\hline Pisang raja & 6 & 15 & 5,71 & 1,06 & $1 \mathrm{x} /$ hari \\
\hline Madu & 4 & 10 & 1,5 & 0,73 & 1x/hari \\
\hline
\end{tabular}

* Rata-rata konsumsi berdasarkan jumlah responden yang mengonsumsinya

** Beban glikemik didapatkan dari hasil kali indeks glikemik per bahan makanan dengan jumlah gram karbohidrat dalam bahan makanan tersebut. Rata-rata beban glikemik berdasarkan jumlah responden yang mengonsumsinya

Bahan makanan tinggi beban glikemik yang sering dikonsumsi oleh responden yaitu nasi putih dan gula pasir dengan frekuensi 2-3x/hari. Rata-rata konsumsi per hari nasi putih sebanyak 248,75 gram dengan beban glikemik sebesar 63,36 gram dan rata-rata konsumsi gula pasir per hari oleh responden adalah 16,76 gram dengan beban glikemik sebesar 11,06 gram. Gula pasir diperoleh dari konsumsi dalam bumbu masakan, dikonsumsi bersama jus atau minuman lain namun tidak semua responden mengonsumsi gula pasir saja karena terdapat beberapa responden yang mengonsumsi gula khusus bagi penderita diabetes mellitus.

\section{Kadar Glukosa Darah}

Hasil dari pemeriksaan kadar glukosa darah puasa dapat dikategorikan menjadi dua kategori yaitu kadar glukosa darah normal <126 mg/dL dan kadar glukosa darah tinggi $\geq 126 \mathrm{mg} / \mathrm{dL}$. Berikut 
ini merupakan distribusi responden menurut kadar glukosa darah puasa, yaitu:

Tabel 6. Distribusi Responden Menurut

Kadar Glukosa Darah Puasa

\begin{tabular}{lc}
\hline \multicolumn{1}{c}{ Statistik } & Kadar Glukosa Darah \\
Deskriptif & Puasa $(\mathrm{mg} / \mathrm{dL})$ \\
\hline Mean & 149,25 \\
Std. Deviation & 60,02 \\
Minimum & 78 \\
Maximun & 284 \\
\hline
\end{tabular}

Tabel 6 menunjukkan bahwa ratarata responden memiliki kadar glukosa darah puasa sebesar $149,25 \mathrm{mg} / \mathrm{dL}$ yang termasuk dalam kategori tinggi $(\geq 126$ $\mathrm{mg} / \mathrm{dL})$. Data distribusi responden menurut kategori kadar glukosa darah puasa menunjukkan bahwa persentase responden dengan kadar glukosa darah puasa yang normal sama dengan persentase responden dengan kadar glukosa darah yang tinggi yaitu masingmasing adalah 50\% (20 orang).

\section{Hubungan Asupan Serat dengan Kadar Glukosa Darah}

Serat makanan memiliki fungsi yang sangat penting dalam pemeliharaan kesehatan, pencegahan penyakit dan sebagai komponen penting dalam terapi gizi (Mahan dan Escott-stump, 2008). Makanan berserat tinggi dapat membantu dalam menurunkan kadar glukosa darah yaitu dengan meningkatkan rasa kenyang lebih lama (Rimbawan dan Siagian, 2004). Mekanisme serat dapat membantu menurunkan kadar glukosa darah yaitu serat makanan terutama serat larut air dapat membentuk makanan lebih viskos (membentuk gel) dan menjadikan makanan tidak tercerna oleh enzim pencernaan. Makanan yang telah lebih viskos akan memperlambat proses pengosongan lambung dan menyebabkan pencernaan makanan menjadi lambat. Pencernaan yang lambat ini menyebabkan terjadinya penurunan penyerapan nutrisi termasuk glukosa. Dari pengosongan lambung yang melambat dan pencernaan yang lambat menciptakan rasa kenyang lebih lama, membuat asupan makan menjadi menurun. Adanya penurunan penyerapan glukosa dan asupan makan menurun akan menjadikan kadar glukosa darah lebih rendah/normal. Pada mekanisme selanjutnya dari serat yang tidak dapat dicerna oleh enzim pencernaan akan menyebabkan serat makanan masuk ke dalam usus besar dalam keadaan utuh. Serat yang masih utuh dalam usus besar kemudian difermentasi oleh bakteri di usus besar membentuk SCFA (ShortChain Fatty Acid). Pembentukan SCFA ini menginduksi sekresi hormon GLP-1 (Glucagon Like Peptide-1), GIP (Gastric Inhibitory Polypeptide), dan PYY (Peptide $Y Y$ ) yang akan meningkatkan sensivitas insulin dan akhirnya menyebabkan penurunan kadar glukosa dalam darah (Sumarti, 2017).

Dari hasil uji statistik dengan menggunakan Pearson Product Moment (Tabel 10), diperoleh nilai $\mathrm{p}=0,042$ ( $\mathrm{p}$ value <0,05) yang berarti bahwa ada hubungan antara asupan serat dengan kadar glukosa darah puasa pada pasien diabetes melitus tipe 2 di Klinik Jasmine 2 Surakarta. Hal ini sejalan dengan hasil penelitian Sari yang menyatakan bahwa ada hubungan antara asupan serat dengan kadar glukosa darah puasa pada pasien rawat jalan diabetes melitus tipe 2 di RSUD Dr. Moewardi Surakarta (Sari, 2015). 
Tabel 7. Distribusi Frekuensi Kadar Glukosa Darah Puasa Berdasarkan Asupan Serat pada Pasien Diabetes Melitus Tipe 2

\begin{tabular}{|c|c|c|c|c|c|c|c|}
\hline & \multicolumn{4}{|c|}{ Kategori Kadar Glukosa Darah Puasa } & \multirow{2}{*}{\multicolumn{2}{|c|}{ Total }} & \multirow{3}{*}{$\mathrm{p}$ value* } \\
\hline & \multicolumn{2}{|c|}{ Normal } & \multicolumn{2}{|c|}{ Tinggi } & & & \\
\hline & $\mathrm{N}$ & $\%$ & $\mathrm{n}$ & $\%$ & $\mathrm{~N}$ & $\%$ & \\
\hline Asupan Serat & & & & & & & \\
\hline Rendah & 20 & 50 & 20 & 50 & 40 & 100 & 0,042 \\
\hline Cukup & 0 & 0 & 0 & 0 & 0 & 0 & \\
\hline
\end{tabular}

*Uji Pearson Product Moment

Berdasarkan Tabel 7 terdapat 20 responden dengan asupan serat rendah namun memiliki kadar glukosa darah yang normal. Hal ini dapat terjadi ketika responden mengonsumsi bahan makanan sumber serat yang juga memiliki indeks glikemik yang rendah dengan porsi yang sedikit/normal, sehingga menjadikan asupan serat rendah dan beban glikemik yang dihasilkan dari bahan makanan tersebut juga rendah.

\section{Hubungan Beban Glikemik dengan Kadar Glukosa Darah}

Konsumsi makanan dengan beban glikemik tinggi ketika tubuh mengalami resistensi insulin, menyebabkan tubuh akan merespon dengan meningkatkan sekresi insulin. Sekresi insulin yang terus meningkat akan menyebabkan sel- $\beta$ pankreas kelelahan dan pada akhirnya sel- $\beta$ pankreas tidak dapat memenuhi kebutuhan insulin, sehingga glukosa dalam darah tetap tinggi (Wilet dkk, 2002).

Konsumsi beban glikemik yang rendah akan menghambat laju dari sistem pencernaan terutama pada daerah lambung sehingga menyebabkan waktu pengosongan lambung akan lebih lama (gastric emptying rate). Makanan di dalam lambung yang sudah dipecah dan dicerna menjadi kimus akan terhambat saat menuju usus kecil (duodenum), sehingga proses penyerapan glukosa pada usus duodenum dan jejunum terjadi secara lambat dan akhirnya laju penyerapan glukosa darah akan turun. Makanan dengan beban glikemik rendah juga akan menekan sekresi insulin pankreas sehingga lonjakan kadar glukosa darah tidak terjadi (Simin dkk, 2004).

Tabel 8. Distribusi Frekuensi Kadar Glukosa Darah Puasa Berdasarkan Beban Glikemik pada Pasien Diabetes Melitus Tipe 2

\begin{tabular}{cccccccc}
\hline & \multicolumn{9}{c}{ Kategori Kadar Glukosa Darah } & \multirow{2}{*}{ Total } & \multirow{2}{*}{ p value valu $^{*}$} \\
\cline { 2 - 5 } & \multicolumn{9}{c}{ Normal } & \multicolumn{2}{c}{ Tinggi } & & \\
\cline { 2 - 6 } & $\mathrm{n}$ & $\%$ & $\mathrm{n}$ & $\%$ & $\mathrm{~N}$ & $\%$ & \\
\hline Asupan Beban Glikemik & & & & & & & \\
Rendah & 0 & 0 & 0 & 0 & 0 & 0 & 0,001 \\
Sedang & 16 & 40 & 2 & 5 & 18 & 45 & \\
Tinggi & 4 & 10 & 18 & 45 & 22 & 55 & \\
\hline
\end{tabular}

*Uji Pearson Product Moment

Hasil penelitian menunjukkan bahwa sebagian besar yaitu $55 \%$ responden/subjek penelitian memiliki beban glikemik tinggi dengan kadar glukosa darah puasa normal sebesar $10 \%$ dan kadar glukosa darah puasa tinggi 
sebesar 45\%. Dari hasil uji statistik dengan menggunakan Pearson Product Moment (Tabel 11), diperoleh nilai $\mathrm{p}=0,001$ ( $\mathrm{p}$ value $<0,05$ ) yang berarti bahwa ada hubungan antara beban glikemik dengan kadar glukosa darah puasa pada pasien diabetes melitus tipe 2 di Klinik Jasmine 2 Surakarta. Hal ini sejalan dengan hasil penelitian yang dilakukan oleh Immawati dan Wirawanni (2014), yang menyatakan bahwa ada hubungan yang bermakna antara beban glikemik dengan kadar glukosa darah puasa pada pasien diabetes melitus tipe 2 dengan nilai $\mathrm{p}=0,019$.

\section{KESIMPULAN}

Berdasarkan hasil penelitian, dapat disimpulkan bahwa ada hubungan antara asupan serat terhadap kadar glukosa darah pada pasien diabetes melitus tipe 2 di Klinik Jasmine 2 Surakarta dengan nilai $\mathrm{p}=0,042$ dan ada hubungan antara beban

glikemik terhadap kadar glukosa darah pada pasien diabetes melitus tipe 2 di Klinik Jasmine 2 Surakarta dengan nilai $\mathrm{p}=0,001$. Semua responden/subjek penelitian memiliki asupan serat yang rendah dan sebagian subjek penelitian memiliki asupan beban glikemik yang tinggi. Diharapkan bagi responden untuk lebih memperhatikan pola konsumsi dengan diet yang tepat seperti mengonsumsi makanan serat tinggi dan beban glikemik rendah untuk mengontrol kadar glukosa darah.

\section{UCAPAN TERIMAKASIH}

Terimakasih kepada Klinik
Jasmine 2 Surakarta yang telah
memberikan data-data yang kami
butuhkan untuk menunjang penelitian dan
terimakasih kepada responden (pasien DM
tipe 2) atas kerjasamanya, sehingga
penelitian bisa berjalan dengan lancar.

\section{DAFTAR PUSTAKA}

Alwi, I., Setiyohadi, B., Siamadibrata, M.K., Sudoyo, A.W, Setiati, S. (2007). Buku Ajar Penyakit Dalam. Pusat Penerbitan Buku Ajar Ilmu P.enyakit Dalam. Jakarta: Departemen Ilmu Penyakit Dalam FKUI

Burani, J. Gushers dan Tricklers. (2006). Practical Use of the Glycemic Index. Florida: American Diabetes Association Southern Regional Conference Marco Island. Tersedia dari; URL; http://www.ecmstudy.com/uploads/3/1/8/8/31885023/glycemicindex.pdf

Burani, J., Longo, P.J. (2006). Low-Glycemic Index Carbohydrates: An Effective Behavioral Change for Glycemic Control and Weight Management in Patients With Type 1 and 2 Diabetes. The Diabetes Educator.

Chandalia, M., Garg, A., Lutjohann, D., Von B.K., Grundy S.M., Brinkley L.J. (2000). Beneficial Effects of High Dietary Fiber Intake in Patients with Type 2 Diabetes Mellitus. N Engl Journal Med; 342: 1392-1398.

Goldenberg, R., Punthakee, Z. (2013). Definition, Classification and Diagnosis of Diabetes, Prediabetes and Metabolic Syndrome. Canadian Journal of Diabetes. 37: 8-11

Idris, A.M., Jafar, N., Indriasari, R. (2014). Pola Makan dengan Kadar Gula Darah Pasien DM Tipe 2. Jurnal MKMI. 10(4): 211-218 
Immawati, F.R., Wirawanni, Y. (2014). Hubungan Konsumsi Karbohidrat, Konsumsi Total Energi, Konsumsi Serat, Beban Glikemik dan Latihan Jasmani dengan Kadar Glukosa Darah pada Pasien Diabetes Mellitus Tipe 2. JNH; 2(3).

Kementerian Kesehatan RI. (2014). Situasi dan Analisis Diabetes. Jakarta Selatan: Pusat Data dan Informasi

Mahan, K.L., Escott-Stump. (2008). Krause's Food and Nutrition Therapy. Canada : Elsevier: Edition 12

Perkeni. (2015). Konsensus Pengolahan dan Pencegahan Diabetes Melitus Tipe 2 di Indonesia 2015. PB Perkeni

Rimbawan, Siagian, R. (2004). Indeks Glikemik Pangan. Jakarta: Penebar Swadaya

Riskesdas. Hasil Utama Riskesdas 2018. (2018). Jakarta: Badan Penelitian dan Pengembangan Kesehatan Departemen Kesehatan, Republik Indonesia

Sari, AL. (2015). Hubungan Asupan Serat terhadap Kadar Glukosa Darah Pasien Rawat Jalan Diabetes Mellitus Tipe II di RSUD Dr. Moewardi [karya tulis ilmiah]. Surakarta: Program Studi Ilmu Gizi Fakultas Ilmu Kesehatan Universitas Muhammadiyah Surakarta

Simin, S., Schulz, M.B., Rimm, E.B., Manson, J.E., Willet, W.C., Hu, F.B. (2004). Glycemic Index, Glycemic Load, Dietary Fiber Intake and Incidence of Type 2 Diabetes in Younger and Middle-aged Woman. Am j clin nutr. 80: 348-356.

Sunarti. (2017). Serat Pangan dalam Penanganan Sindrom Metabolik. Yogyakarta: Gadjah Mada University Press

Willet, W., Manson, J., Liu, S. (2002). Glycemic Index, Glycemic Load, and Risk of Type 2 Diabetes. Am J Clin Nutr. 76 (1): 274-280. 